\title{
The role of geosciences and landscape in the management of Natural Parks of Guadalajara (Central Spain): in search of suitable applications
}

\author{
A. García-Quintana, M. P. Abad, M. Aguilar, L. Alcalá, I. Barrera, \\ M. Cebrián, M. C. Fernández de Villalta, J. F. García-Hidalgo, \\ R. Giménez, A. E. Godfrey, J. A. González-Martín, A. Lucía, \\ J. F. Martín-Duque, M. Martín-Loeches, E. Quijada, \\ J. M. Rodríguez-Borreguero, R. Ruiz López de la Cova \& A. Solís \\ PANAGU Project, Complutense University, Spain
}

\begin{abstract}
University professors, researchers and professionals from different governmental bodies in Madrid and Guadalajara have formed a research group to investigate how to use geo-environmental information in the management of Spanish Natural Parks. Funding has been obtained from the Spanish Ministry of Science and Technology. The pilot area for the project is the Natural Parks of the province of Guadalajara in the Castilla - La Mancha Autonomous Region.

This article describes two proposals to analyse the physical environment and the landscape of the natural parks of Guadalajara: analytical-parametric inventory, and synthetic-physiographic inventory. The objective is to provide useful information on how to manage these areas. Additionally, the article includes results of the study of active karstic processes in two of these natural parks, Río Dulce and Alto Tajo.

Keywords: natural parks, landscape, environmental geology, karstic processes, Guadalajara.
\end{abstract}

\section{Introduction}

Landscape and geology are often the most important factors leading to the designation of an area as a national or natural park. This has been the case since the beginning of the national park movement in North America (Yellowstone 
1872, Waterton Lakes 1885) and in Spain (Picos de Europa, Ordesa and Monte Perdido, 1918). However, once a park is established, geological and landscape value tends to be relegated to a secondary role in the daily management of such places. Growing interest in the preservation of fauna and flora during the second half of the $20^{\text {th }}$ century, the ambiguity of the term "landscape", and a lack of general knowledge about geology on the part of Mediterranean societies have all been obstacles to parks' maximizing and managing these resources.

Faced with this reality, studies on geology and landscape appear to be undervalued and underutilised in the management of natural places in many countries, among them Spain. This limits the chances that societies will protect, enjoy, and value these areas. Nevertheless, the information from such studies can provide: knowledge about active processes, conceptual tools, classifications, and territorial compositions, predictions, evaluations, etc.

This perceived deficit is the starting point for the PANAGU project. Landscape is the "meeting point" of the project's component parts, as it is the most conspicuous and highly valued element in most natural parks. We believe that analysing geology and geomorphology can provide a well-informed understanding of landscape. Landforms (bedrock, topography and processes) affect microclimate conditions, soils, vegetation, land use and the visual composition of many of the natural parks of the Iberian Peninsula. For this reason, although the research team is led by geologists and geomorphologists, other specialists on landscape are also involved.

\section{Geological and geographical setting}

The province of Guadalajara is situated on the Meseta, a region composed of wide barren plains and mountain chains. This morphological unit occupies the greater part of the Iberian Peninsula; it has an average altitude of 600 m.a.s.l. and constitutes the Peninsula's dominant geographic element. Three types of landscape stand out: mountains, open plains, and gorges cut into the plains. The gorges are the result of the big difference in altitude between the central zone of the Meseta and sea level. The three natural parks of Guadalajara offer fine examples of these landscapes. The province of Guadalajara is shaped by the three large regional geological units that intersect there: the Central System, the Iberian Chain and the Tajo Basin.

The Central System is a reactivation and uplift of the ancient Variscan Massif, composed predominantly of metamorphic and igneous rocks. The Tejera Negra is located in this Central System. It is quite small (1,600 ha) and was created to protect a relic beech tree (Fagus selvatica) forest, although its name is due to the presence of stands of yews (Taxus baccata, in Spanish tejeras). The park has relatively simple topography shape and a fairly uniform geological composition. It is characterised by sharp peaks and crests that rise above 2000 m.a.s.l., sculpted from quartzite and black slate of Ordovician age. It is poorly developed, far from large population centres, and has low human impact. At present, there is a proposal to considerably expand the park's size due to the beauty and untouched nature of much of the surrounding area. 
The Iberian Range is a foreland mountain chain, with a very thick sedimentary layer predominantly of carbonate rocks. Due to intense erosion during the Neogene, today it appears as a set of barren plains from which some residual mountain chains jut out. These mountains control the shape of the stream network. The Río Dulce and the Alto Tajo are situated in the Iberian Range. Both parks are characterised by narrow, deep canyons and river gorges which in places can drop to $500 \mathrm{~m}$ below the plains and plateaus, located at $1,100 \mathrm{~m}$ above sea level.

The Río Dulce Natural Park (literally, "Sweetwater River", because it does not have a high percentage of salts, unlike other rivers in this region which have been exploited for their salts since the days of the Roman Empire because they drain salty Triassic formations) is small in size $(8,300 \mathrm{ha})$ and, although its main landscape types are gorges and plains, it has a more complex topographic structure. The plains have different shapes and land uses as they are developed on substrates of different lithologies and structures. The same can be said of the Rio Dulce and its tributaries. This has led to a diversity of landscapes. There has also been greater human impact, thanks to its location near the historic city of Sigüenza, today a magnet for cultural and gastronomic tourism. Since the Middle Ages, the area has been well travelled, first by two drovers' routes and royal roads that passed close by. Today it is flanked by a national highway, a regional highway, and it can be traversed by a local road.

The Alto Tajo natural park (literally, "High Valley" of the "Cut River") is larger (106,000 ha). It constitutes one of the most unique natural areas on the Iberian Peninsula so its designation as a national park is under consideration. The park is famous for its deeply incised fluvial network. There are more than 100 $\mathrm{km}$ of spectacular canyons, deep gorges, and narrow valleys with steep slopes, some covered by thick forests. To this scientifically and aesthetically interesting geo-morphologic setting one must add geological, plant and ethnographic formations that make the park a valuable national heritage site: unique large sedimentary structures, juniper groves (Juniperus thurifera), and "pallozas" (primitive dwellings of pre-Roman technology).

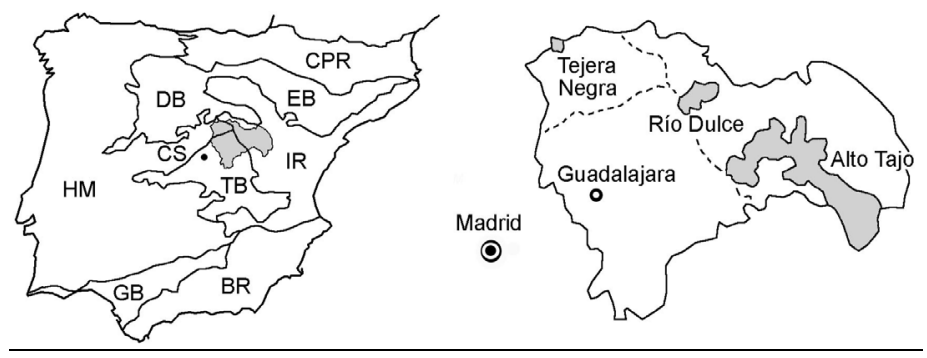

Figure 1: Location of the three natural parks within the regional geological units of Guadalajara and the Iberian Peninsula. DB, Duero Basin; IR, Iberian Range; CS, Central System; TB, Tajo Basin; EB, Ebro Basin; BR, Betic Range; GB, Guadalquivir Basin; HM, Hercynian (Variscan) Massif, CPR, Cantabrian Pyrenees Range. 


\section{The landscape study of the natural parks of Guadalajara}

The primary and operative objective of the PANAGU Project is to carry out an analysis of the landscape of the protected natural areas of the province of Guadalajara (Castilla-La Mancha). This analysis is first and foremost cartographic and digital and is being performed following two concepts.

\subsection{Analytical or parametric method}

The analytical or parametric method examines a series of maps and thematic reports, whose partial results are integrated to establish the true relationship between different elements of the environment.

\subsubsection{Lithology and tectonic structure}

In this research, rocks are studied not so much for their own sake but rather as to how they condition ecosystems, human uses and landscape. Therefore, using a standard 1/50,000 geological map, lithological maps were compiled that grouped rock units with a high degree of physical and chemical homogeneity, and whose ecological and visual response were also homogeneous. A subsequent evaluation of these units allowed the capabilities and limitations of use to be established as well as their relationships with other environmental factors.

For each scenic landscape site, the size, orientation and form of each topographic element, as well as the surface area, intensity and type of land uses and the placement of human settlements and developments can be explained in the litho-structural configuration of the different plots in the territory. Each body of rock provides at least one distinguishing property to the landscape: colour, alteration, texture, permeability, forms of erosion, etc. The tectonic structure affects the park's landscape on a larger scale, such as: surface forms, folded areas with irregular relief, valleys oriented along faults, etc.

Detailed analysis of the parks' territory by a large group of experienced professionals revealed geological formations that should be of aesthetic interest to the public, and of scientific interest as national treasures, but which at the moment are underappreciated. These include ancient valleys with hanging formations, karst systems cut by modern valleys, prehistoric landslides, etc.

\subsubsection{Relief and topography}

The study of landforms plays a fundamental role in the study of landscape. From a strictly visual standpoint, landforms mould both the viewpoints and the view shed. Within the framework of the study of "natural scenarios", it seems necessary to make an objective classification of the landforms and their characteristics if we want to be able to measure, correlate and study a landscape. In so doing we facilitate comparison of the results of the different studies.

The way to accomplish this objective is through a mathematical manipulation of numerical data that can be computer processed. Therefore, we use the Digital Elevation Models (DEM), as an approximation of reality.

In general, the DEM creates a representation of physical phenomena, in this case the ground surface, from a spatial, geometric point of view. This digital 
representation is, by definition, only an approximation to reality through a finite sample of values and a set of functions.

In order to achieve the best adaptation possible to the phenomenon it represents, the project used the geodesic reference system (ED50) and the UTM projection (huso 30), the official system of Spanish cartography. The DEM has a $25 \mathrm{~m}$ grid spacing, and the data are referenced to the Alicante sea level datum.

Accordingly, the DEM fulfils two functions. On the one hand, it computes relief and its derivatives (slopes, orientations, curvatures, etc.). These characteristics constitute a Digital Terrain Models (DTM). On the other hand, the DEM serves as a basis for geo-referencing other thematic maps.

The project will attempt, on the basis of this modelling of the landscape features of the three natural parks of Guadalajara, to acquire a fuller knowledge of the physical condition and construct a tool to improve management and planning of these protected natural places. All this information is being processed with the help of appropriate software, a Geographical Information System, whose purpose is to optimise and facilitate analysis of the data.

\subsubsection{Hydrogeology}

Understanding groundwater is very important to the management of the Río Dulce and Alto Tajo natural parks. Most of both parks are underlain by karstic aquifers, highly susceptible to contamination. Hydrogeological research is focused on the precise localisation of the groundwater recharge areas, as these are the points where potentially contaminating agricultural or livestock activities can be regulated.

In some cases recharge occurs outside the park boundaries, so that the mapping of these areas is necessary to justify their protection. The precision of this research includes carrying out classic tracer tests. The protection limits should also take the discharge points into account, some of which appear to be independent of the river basins.

Also important in their implications for the management of these two parks are the hydro-geochemical processes in the Keuper facies that result in mineralized springs. The deposited minerals are essential to plant growth and attract certain animals in search of water and dietary salt.

The metamorphic bedrock and mountainous relief which predominate in the Tejera Negra natural park prevent any significant infiltration of precipitation. However, we intend to monitor the permeability of the numerous debris flows, scree slopes and areas of surface alteration to determine their contribution to base flow and response times.

\subsubsection{Soils}

Soils are one of the more dynamic components of any landscape. They are constantly being formed by physical, chemical, and biologic processes. They are essential to the maintenance of a healthy ecosystem, especially in these natural parks.

Land management without adequate knowledge of soils and their correct handling have in many cases destroyed what they intended to conserve. Such actions have damaged the entire natural environment and increased erosive 
activity on the remaining resources, with the consequent modification of the landscape. This is especially true in these areas of the Iberian Peninsula where the severity of current climatic favours intense soil destruction. Conserving the soil resources depends on a complex combination of economic factors, on the knowledge of conservation means and techniques, and on the possibilities within the social environment which favour it.

For this reason, the soil surveys of the three natural parks in Guadalajara consist of a soils mapping and the evaluation of how vulnerable they are to physical and chemical degradation.

\subsubsection{Vegetation}

The plant cover often hinders the observation of underlying geological elements. However, the specialised observation of the plant cover allows the geological characteristics hidden from sight to be deduced.

The relationship and correspondences between geology and botany have long been dealt with and written about from very different viewpoints: from those who consider geology as a secondary factor [1] to those who put it first when justifying the discontinuities and even the vegetation typology [2]. The most obvious approximations, such as those in cases of azonal vegetation [3], or in the ridge crest-slope-valley floor models, are relatively easy, but more complex approaches can lead to difficulties. The discrepancies and difficulties are due above all to the web of complex relationships within the natural environment and also to the different rhythms of geological and vegetation processes.

When geology is cited as the vegetation controller there are many factors involved, for example topography, lithology, chemical composition, $\mathrm{pH}$, joints, soil development... Further, each factor can vary in importance depending on the case. Some medium-scale $(1 / 50,000)$ studies carried out by drawing up independent thematic mappings have produced only partly satisfactory results [4]. The destruction of the plant cover and its spontaneous recovery tendency, are the origin of the mosaics of different plant communities existing within geologically uniform areas because of differing regeneration requirements. But in most cases, the botanical component of the landscape mirrors the history of land uses. To overcome these problems requires the use of mapping units which combine arrangement and dynamism [5], grouping complexes of plant communities linked to each other through dynamic relationships or "eucomplexes", and separating them from the mosaics of communities without these relationships (the so-called "geo-complexes").

Within this framework, one of the aims of the PANAGU project is to discover the spatial and mapping coincidences between these units, eucomplexes, catenas and mosaics, and the synthetic units defined by the geo-edaphic elements which model the landscape, lithology, topography and processes. In this way the analysis of the "visual" landscape, where the plant cover is an important element, can be completed.

\subsubsection{Visual landscape}

The visual elements of a landscape are probably the first and most noticed by the general public in the three natural parks of Guadalajara. Since it is the result of 
all past geologic, climatic, and vegetative history, it is truly integrative. Although the landscape constitutes the integrating element of the whole project, its "specific" study is approached with four premises: a) to prioritise the correlation between the compositional and visual properties of the territory; b) to build a typological classification for the territory of the parks and their surroundings; $c$ ) to carry out a specific mapping of landscape types; and d) to analyze the visual scenarios and their relationship with geology (rocks, structure, morphogenetic processes). Given that the three natural parks have different characteristics, different aims have been set and different methodologies followed for each area.

For the Río Dulce natural park a detailed mapping of landscape scenarios has already been carried out (Fig. 2), along with a catalogue and a genetic classification. Three main scenario groupings have been differentiated: (a) the more-or-less flat uplands; (b) the narrow valleys of the Río Dulce and some of its tributaries; and (c) slopes of transition territory between groups A and B. The geological substratum of the uplands conditions its partial erosion and the agricultural use. Thirty upland scenarios have been distinguished, belonging to ten landscape types. Nineteen valley scenarios have been distinguished, grouped in six landscape types. Thirty five transition area scenarios have been differentiated, belonging to six landscape types.

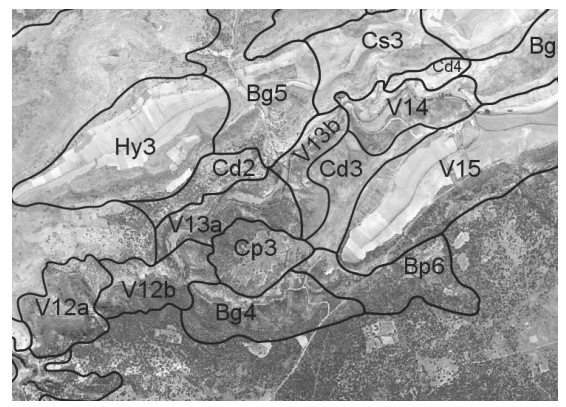

Figure 2: Example of landscape mapping in the Río Dulce natural park.

\subsubsection{The artistic contribution}

Science, at its core, really means the scientific method, a way of observing or accessing nature from the senses and reasoning, from observation and the making of hypotheses, from verification and raising them to the category of scientific theories or relative interpretation models. It is never absolute, but rather subject to changes in time, in line with advances in other fields such as technology. Art, however, can be defined historically: we cannot confine it to a single conception. We can only say that art is the way artists interpret nature, so that there will always be as many "arts" as there are artists, although it is true that there are certain categories which repeat themselves throughout the history of art. They are driven by the search for expression, for harmony, for beauty, etc.

Every artist sees the landscape according to his or her own sensitivity, and for this reason it is an open-ended way of looking, a poetic reading of nature, 
receptive to suggestions and to the recognition of signs and symbols of every sort. The scientific reading of the landscape, on the other hand, although not without sensitivity, gives a reading in prose, demanding in its words, in the concepts and in the rigorous and systematic description of the medium. In this context, the artistic contribution to this project attempts to: (1) represent the different landscape typologies obtained from their classification; and (2) make abstractions from the different elements which make up the landscape (Fig. 3).
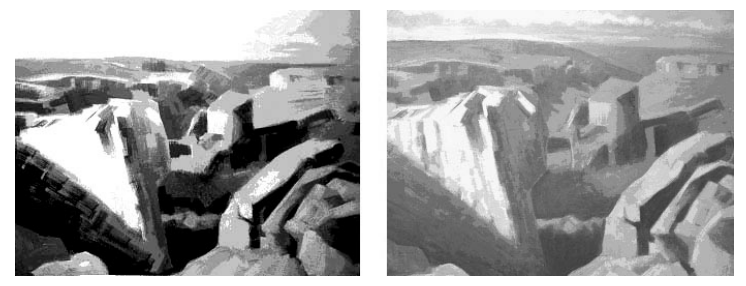

Figure 3: The artistic representation allows the abstraction of the landscape components; left, geological skeleton; right, a delicate tapestry of vegetation provides the visible scenario (M. Cebrián).

\subsection{Synthetic or physiographic method}

The integrated study of the landscape, represented in maps of homogeneous territorial units, is being carried out on the basis of geologic and geomorphologic information, which are given an integrated content through the progressive and comprehensive inclusion of existing ecological relationships, and not simply by addition by the use of overlays of other elements, such as soils or vegetation.

\subsubsection{The mapping of landscape elements in the Tejera Negra natural park}

The bedrock of this natural park is mostly a series of highly fractured Silurian and Ordovician black slates. These slates are exposed in numerous surface outcrops. In the higher areas there is discontinuous debris overburden while in the lower areas colluvium overburden can be found. Finally, the main rivers, the Lillas and the Sorbe, flow over an alluvial deposit of some depth.

A detailed geomorphological mapping (scale 1:25,000) of the whole natural park is being carried out because of the importance it has for understanding soil development, and subsequently for vegetation. This mapping is of the synthetic or physiographic type, not the morphogenetic as it will look at and describe bedrock plus landform. This mapping of the landforms will then be used to analyse the relationship of the soils and finally the relationship of these soils with the existing vegetation types.

The aim is to obtain a map of the homogeneous territorial units in detail, or "landscape elements". We intend that the characterisation and evaluation of these units, both ecological and visual, will provide useful information for the management of this natural area. 


\section{Active karstic processes in the Guadalajara natural parks}

The methodology proposed in the previous paragraph attempts to approach the study of the physical environment and the landscape of the natural parks in Guadalajara from an integral and methodological point of view. Another essential aim of the PANAGU project is the characterisation and quantification of the geologic and geomorphologic processes active in these karstic parks, in so far as these processes form part of the natural dynamic, with repercussions for ecological and human activity.

\subsection{Tufa deposits in the Alto Tajo Natural Park}

In the Alto Tajo Natural Park there are numerous karstic features, which are undoubtedly of landscape, environmental and scientific interest $[6,7,8]$ ). Among these, there are numerous outstanding tufa deposits. They range in age from Neogene to late Holocene times with some still currently active, although their growth is increasingly slow. From the paleoclimatological point of view, the tufa deposits are contemporary with the last karstification periods which occurred in the Iberian Chain throughout the Quaternary Age. They developed during the Marine Oxygen Isotopic Stages (OIS), especially the odd numbers 7, 5 and 1 , in Mediterranean climates characterised by high humidity and by development of the plant covers $[9,10])$. Within the Alto Tajo natural park, the following tufa typologies can be distinguished:

a) Perched springline tufas developed from important karstic springs. They are the most numerous and spectacular tufa build-ups in the canyon of the Alto Tajo [10] due to the sizes. They reach volumes larger than a million $\mathrm{m}^{3}$. Their outcrop geometry is composed of tiers with subhorizontal tops leading to waterfalls of considerable height containing fossil or functional moss curtains. Their stratigraphy contains tufas with different petrological facies. There are also included fluvial deposits, periglacial lithoclast microbreccias, and paleosols which result from a varied paleoclimatic record [10].

b) Fluvial tufas. The narrow, deeply cut gorges carved out by the Tajo river controlled the genesis of the numerous phytoherm barrages of different palaeoclimatic stages. These barrages are frequently located close to knickpoints associated with differential erosion of the underlying Mesozoic strata. The oldest generation of these barrages, lower Pleistocene, is placed some $200 \mathrm{~m}$ above the river bed of the Alto Tajo, while the most recent is Holocene and can be found at 5 to $10 \mathrm{~m}$ above the stream (Fig. 4) [10]. In the ponded areas upstream of the dams there are accumulations of abundant fine materials of tufaceous origin. In some non-contaminated stretches of the river in the Alto Tajo there are certain stromatolite groups currently growing laterally in the channel margins [11]. These are deposits of microbial origin and have not yet been investigated in spite of their rarity in Mediterranean river beds.

The tufaceous deposits of the area key elements in establishing the most recent evolution of karstic landscapes. In fact, during the Holocene, numerous tufa barrages formed an authentic fluviolacustrine landscape (Fig. 4) in the Alto Tajo and in some of its tributaries [10]. After the Bronze Age, these systems 
became degraded by human impact. As a result, in the Iron Age certain valleys record a change in their sedimentary dynamic caused by the removal of the plant cover for agriculture, cattle rearing or metal working activities. The numerous terrigenous deposits, which reached the river beds from the slopes, put an end to the precipitation stage of the carbonates and to the construction of the tufa barrages. The increasingly numerous detrital deposits gradually destroyed these vulnerable natural structures. At the present time, only one grouping of functional barrage survives in the Alto Tajo, which dams the Taravilla Lake.

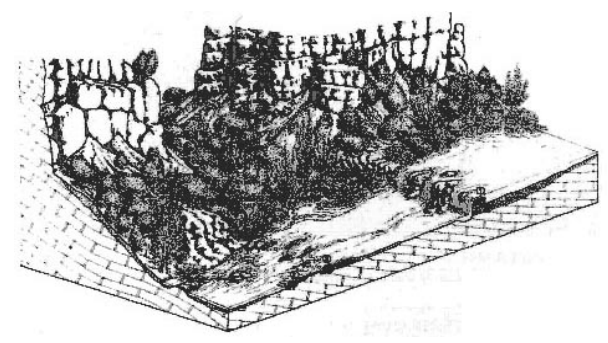

Figure 4: Sketch showing one hypothetical Holocene barrage tufa in the Alto Tajo Valley (Bronze Age, 3,500 B.P.) (in [12] p. 160.)

\subsection{Karstic erosion of the Río Dulce natural park}

One of the most active geomorphologic processes in the Río Dulce natural park is karstic erosion. The Río Dulce runs along the floor of a narrow canyon cut in a Jurassic and Cretaceous limestone and dolostone plateau, where it is fed by various karstic springs. The recharge of these springs is from the plateau, which hardly shows any drainage. The precipitation filters through the soil and into the numerous fractures in the rock below. To determine the chemical dissolution rates within the carbonates, a protocol has been set up to periodically sample the waters of springs, for chemical analysis of dissolved ions (Figure 5, Table 1).

Given the river's mainly subterranean contribution, these values may be considered as representative of the Río Dulce. This means that if the quantities of dissolved calcite and dolomite are multiplied by the annual mean flow of the Río Dulce $\left(27.5 \mathrm{hm}^{3}\right.$ at the stream gage at Aragosa, five $\mathrm{km}$ downstream from the La Cabrera spring) the following dissolution volumes are obtained:

1) $225.25 \mathrm{mg} / \mathrm{L}$ of calcite $\times 27.5 \times 10^{9}$ litres / year $=6,194.375 \times 10^{9} \mathrm{mg}$ of calcite $/ 10^{9}=6,194,375$ tons $/ 2.71$ ton $/ \mathrm{m}^{3}=2285.74 \mathrm{~m}^{3}$ of CaCO3 dissolved per year.

2) $70.07 \mathrm{mg} / \mathrm{L}$ of dolomite $\times 27.5 \times 10^{9}$ litres / year $=1,926.925 \times 10^{9} \mathrm{mg}$ of dolomite $/ 10^{9}=1,926.925$ tons $/ 3$ ton $/ \mathrm{m}^{3}=642.30 \mathrm{~m}^{3}$ of $\mathrm{MgCO}_{3}$ dissolved per year.

To sum up, although these results are preliminary and perhaps only valid to give a general idea of the magnitude of the phenomenon, it can be estimated that a total of $2,928.04 \mathrm{~m}^{3}\left(\mathrm{c} .3,000 \mathrm{~m}^{3}\right)$ of rock is dissolved annually in the karstic system drained by the Río Dulce within the natural park. 


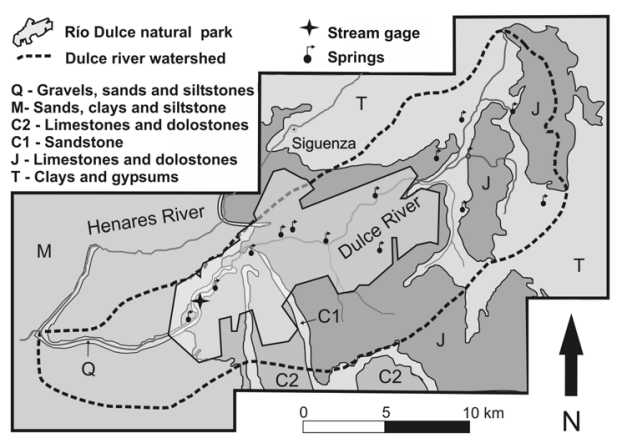

Figure 5: The Río Dulce natural park and its hydrological setting: Dulce river watershed, springs, stream gage and bedrock lithology.

Table 1: The mean content of calcite and dolomite dissolved in the water from the Río Dulce springs, for the analyses carried out to date $\left(\mathrm{HCO}_{3}\right.$ total is $296 \mathrm{mg} / \mathrm{l})$.

\begin{tabular}{|c|c|c|c|}
\hline Ions & $\mathrm{Mg} / \mathrm{L}$ & Ions & $\mathrm{mg} / \mathrm{L}$ \\
\hline $\mathrm{Ca}$ & 90.2 & $\mathrm{Mg}$ & 20.2 \\
\hline $\mathrm{HCO}_{3}$ dependent $(\mathrm{Ca})$ & 135.05 & $\mathrm{HCO}_{3}$ dependent $(\mathrm{Mg})$ & 49.86 \\
\hline $\mathrm{CaCO}_{3}$ & 225.25 & $\mathrm{MgCO}_{3}$ & 70.07 \\
\hline
\end{tabular}

\section{Discussion and conclusions}

By carrying out territorial inventories of the natural parks in Guadalajara using both analytic and synthetic procedures, an attempt is being made to compare the advantages and disadvantages of each of these procedures, as determined by the usefulness of the information obtained. Given that these inventories have not yet been concluded, it is still too early to know which kind of inventory is better adapted to the characteristics of each of the parks.

As far as the tufaceous geo-systems are concerned, it is important to highlight the distinctly high value which their related landscapes offer in the Alto Tajo natural park. This is due to the exceptional dimensions of specific tufaceous deposits, to their "capricious shapes" and to their spectacular waterfalls and the humidity which impregnates the atmosphere of the systems which are still functional, almost all of them sited within the domain of the slopes where they are fed by the karstic springs. These geo-systems, however, are in grave danger: easily degraded and vulnerable to environmental changes. In addition their current growth rates are much slower than several centuries ago. Are recent climatic changes responsible for this? Is human activity the essential reason for this loss of functionality? To delimit the natural and human causes responsible for this deterioration is one of the aims of this project. Fortunately, this fragility is well known and reflected in legislation, thanks to our earlier research. Evidence of this is the protection and conservation framework which covers the tufa outcrops in the recent Law on Nature Conservation and Environmental Impact Assessment passed by the Castilla - La Mancha Government. 
With respect to the volume of rock dissolved in the Río Dulce, 3,000 $\mathrm{m}^{3}$ may seem at first a significant volume, but in proportion to the area and volume occupied by the carbonate massif susceptible to karstification, this dissolution is tiny. Comparison between the annual dissolved volume and the volume of the carbonate rocks of the massif gives that the percentage of this total which is dissolved annually $\left(2 \times 10^{-5} \%\right)$ is not much. This, in turn, allows an approximate calculation of how many years it will take to dissolve the total of the park down to river level (!) or, on the other hand, to carry out evolutionary interpretations of the formation of the canyon and of the park itself.

\section{References}

[1] Cain, S.A., Foundations of Plant Geography, Harper: New York, 1944.

[2] Kruckeberg, A.R. Geology and Plant Life, University of Washington Press: Seattle, 2002.

[3] Walter, E. Vegetation of the Earth and Ecological Systems of the Biosphere, Springer-Verlag: Berlin, 1979.

[4] Forteza, J., Cruz, R., Goy, J., Barrera, I., et al., Soil representation in landscape and geomorphology for the regulation of the Candelario Natural Reserve (Salamanca, Spain), GIS use and limitations. Proc. of the III Int. Congress of European Society for Soil Conservation, Valencia, 2000.

[5] Vigo, J. Some reflections on geobotany and vegetation mapping. Acta Bot. Barc, 45, pp. 535-556.

[6] González Amuchastegui, M.J., Parameras de Molina y el Cañón del Alto Tajo. Guía de los Espacios Naturales de Castilla - La Mancha, pp. 201-202, 1991.

[7] García Quintana, A., García Hidalgo, J.F., Martín Duque, J.F. et al., Geological factors of the Guadalajara Landscapes (Central Spain) and their relevance to landscape studies. Landscape \& Urban Planning, 69, 417-435.

[8] García Quintana, A., Martín Duque, J.F., González Martín, J.F., et al. Geology and rural landscapes in central Spain (Guadalajara, Castilla - La Mancha). Environmental Geology, 47, pp. 782-794.

[9] Ordóñez, S. González, J.A., and García del Cura, M.A., Datación radiogénica (U-234/U-238 y Th-230/U-234) de sistemas travertínicos del Alto Tajo (Guadalajara), Geogaceta, 8, pp.53-56.

[10] González Amuchastegui, M.J. y González, J.A., Significado geomorfológico de las acumulaciones tobáceas del alto valle del río Tajo (sector Peñalen-Huertapelayo). El Cuaternario en España y Portugal, Vol. 1, ITGE, Madrid, pp. 99-109, 1993.

[11] Guerrero, I. y González, J.A., Características geomorfológicos del modelo de construcción tobáceo del Alto Tajo en su fondo de valle (Peralejos de las Truchas, Guadalajara), Geotemas, 1(3), pp. 375-378.

[12] González, J.A. y Rubio, V., Las transformaciones antrópicas del paisaje de los sistemas fluviales tobáceos del Centro de España. Bol. R. Soc. Esp. Hist. Nat. (Geología), 96, pp. 155-186. 